\title{
Rypsi ja soija lypsylehmien valkuaislähteenä
}

\author{
Aila Vanhatalo ${ }^{1)}$, Kevin Shingfield ${ }^{1)}$, Eero Pahkala ${ }^{1)}$, Pirjo Salo-Väänänen ${ }^{2)}$ \\ Hannu Korhonen ${ }^{1)}$, Vieno Piironen ${ }^{2)}$ ja Pekka Huhtanen ${ }^{1)}$ \\ ${ }^{1)}$ Maa- ja elintarviketalouden tutkimuskeskus,31600Jokioinen, etunimi.sukunimi@mtt.fi \\ ${ }^{2)}$ Helsingin yliopisto,PL 27,00014 Helsingin yliopisto,etunimi.sukunimi@helsinki.fi
}

\section{Johdanto}

Kotimaisissa tutkimuksissa valkuaisruokinnan tehostaminen kotimaisilla rypsirehuilla on antanut erittäin hyviä tuotosvasteita. Maitotuotos on lisääntynyt keskimäärin $\mathrm{n} .1 \mathrm{~kg} / \mathrm{d}$ korvattaessa viljaa rypsirehulla säilörehupohjaisella ruokinnalla (Huhtanen 1998). Rypsirehuilla saadut vasteet ovat kuitenkin olleet lineaarisia (Rinne ym. 1999) eli käytetyllä valkuaistasolla ei ole pystytty määrittämään optimitasoa tuotosvasteen kannalta. Muiden valkuaisrehujen, kuten soijan, tuotosvasteista säilörehuruokinnalla on huomattavasti vähemmän tutkittua tietoa käytettävissä. Rypsin ja soijan tuotosvasteita ei ole myöskään vertailtu siten, että tutkimuksessa olisi käytetty useampaa valkuaistasoa.

Koko maitoketjun talouden optimoinnin kannalta pitää tuotosvasteen lisäksi ottaa huomioon mm. vaikutukset maidon prosessoitavuuteen ja ympäristöpäästöihin. Suomessa tuotettavasta maidosta käytetään noin $40 \%$ juustonvalmistukseen. Maidon juustoutumisessa on esiintynyt ongelmia, jotka osittain johtuvat lehmän perimästä. Kotimaisissa tutkimuksissa on kuitenkin osoitettu, että myös valkuaisruokinnalla on merkittävä vaikutus maidon juustoutuvuuteen (Shingfield ym.1999). Toisaalta ulkomaisissa tutkimuksissa on viitteitä runsaaseen valkuaisruokintaan liittyvästä maidon suuresta ureapitoisuudesta, mikä huonontaa maidon laatua juustonvalmistuksen kannalta. Tämä viittaa siihen, että maidon juustoutumisen kannalta olisi olemassa tietty valkuaisruokinnan optimitaso.

Tämän tutkimuksen tavoitteena oli selvittää maitovalkuaisen tuotannon kannalta optimaalinen valkuaistäydennyksen taso ottamalla huomioon maidon juustoutuminen ja juuston laatu. Tutkimuksessa verrattiin soijaa ja rypsirehuja kahdessa Ay-lehmillä tehdyssä maidontuotantokokeessa.

\section{Aineisto ja menetelmät}

Ensimmäisessä kokeessa verrattiin rypsipuristeen (Öpex®) ja soijarouheen annostustason vaikutuksia maitotuotokseen, dieetin sulavuuteen ja veriparametreihin (plasman aminohapot, urea, glukoosi) sekä maidon koostumukseen ( $\mathrm{N}$-fraktiot, rasvahapot, vitamiinit), juustoutumisominaisuuksiin ja hapettumisalttiuteen, jota tutkittiin staattiseen head space -kaasukromatografiaan perustuvalla menetelmällä. Koe tehtiin 16 Ay-lehmällä 'cyclic change over' -kokeena, jossa oli kaksi 8 lehmän blokkia. Koeruokinnat järjestettiin 2 x 4 faktoriaalisesti siten, että kahta valkuaisrehua (rypsipuriste ja soijarouhe) voitiin verrata neljällä isonitrogeenisellä valkuaisen annostustasolla. Lehmille syötettiin vapaasti hyvälaatuista rajoittuneesti käynyttä säilörehua (D-arvo $66 \%$ ) ja $10 \mathrm{~kg} / \mathrm{d}$ viljaväkirehua (ohra, kaura, leike), jota asteittain korvattiin rypsipuristeella ja soijarouheella (rypsipuristetasot $0,1.2,2.4$, ja 3.6 $\mathrm{kg} / \mathrm{d}$, ja soijarouhetasot vastaavasti $0,0.8,1.6 \mathrm{ja} 2.4 \mathrm{~kg} / \mathrm{d}$ ).

Toisessa kokeessa vertailtavina valkuaisrehuina olivat soijarouhe, rypsipuriste (Öpex®) ja rapsirouhe, ja kontrolliruokintana viljaväkirehu ilman valkuaistäydennystä. Myös tässä kokeessa lehmät saivat nurmisäilörehua (D-arvo $67 \%$ ) vapaasti ja väkirehua $10 \mathrm{~kg} / \mathrm{d}$, josta valkuaistäydennetyillä ruokinnoilla korvattiin tutkittavalla valkuaisrehulla kolmen kilon rypsiannosta vastaava valkuaisen määrä. Koemallina oli tasapainotettu 4 x 4 latinalainen neliö, joka toistettiin viitenä erillisenä neliönä. Koe tehtiin 20 Aylypsylehmällä, jotka jaettiin neliöihin poikimakerran ja maidon juoksettuvuuden perusteella. Kokeessa tehtiin samat mittaukset kuin edellisessä kokeessa mutta sen lisäksi koeruokinnoilta kerätyistä maidoista valmistettiin myös juustot.

\section{Tulokset ja tulosten tarkastelu}

Säilörehun kuiva-aineen (ka) syönti ja maitotuotos lisääntyivät lineaarisesti lisättäessä ruokinnan valkuaispitoisuutta rypsipuristeella ja soijarouheella (taulukko 1). Vastoin odotuksia se väkirehun valkuaispitoisuus, jossa tuotosvaste olisi taittunut jäi saavuttamatta vaikka käytetyt valkuaisrehun määrät olivat suuria. Tutkittavina olevista valkuaisrehuista rypsipuriste tuotti kuitenkin merkitsevästi enemmän maitoa ja maitovalkuaista kuin soijarouhe. Sama tulos saatiin myös jälkimmäisessä kokeessa (taulukko 2). Soijarouheella todetut tuotosvasteet olivat n. $30 \%$ huonompia kuin oli odotettavissa soijan 
rehutaulukkoarvon perusteella. Rypsillä saadut tuotosvasteet olivat sen sijaan odotetun mukaisia eli rypsin OIV-arvo vastasi hyvin taulukkoarvoa. Energian saannin osalta rypsi- ja soijaruokinnat olivat hyvin vertailukelpoisia sillä lypsylehmien ME:n saannissa ei ollut eroa vertailtavien ruokintojen välillä. Rypsipuristeen soijaa suurempi rasvapitoisuus kompensoitui soijan rypsiä paremmalla sulavuudella. Jälkimmäisessä kokeessa rypsipuristeen ja rapsirouheen välillä ei havaittu merkitsevää eroa valkuaistuotoksessa (taulukko 2). Myöskään aikaisemmissa kokeissa ei ole todettu tuotoseroja rypsipuristeen ja -rouheen välillä (Rinne ym. 1999, Ahvenjärvi ym. 1999).

Plasman aminohappojen ja urean pitoisuudet sekä maidon ureapitoisuus olivat molemmissa kokeissa yhdenmukaisia eli rypsi lisäsi useiden välttämättömien aminohappojen pitoisuuksia ja alensi plasman ja maidon ureapitoisuuksia soijaan verrattuna osoittaen rypsin valkuaisen tulleen paremmin hyväksikäytetyksi (taulukot 1 ja 2). Soijan huonompi valkuaisen hyväksikäyttö voi liittyä in vivo kokeessa todettuun soijaruokinnan odotettua suurempaan valkuaisen pötsihajoavuuteen (Korhonen ym. 2002). Näin ollen lehmät saivat aminohappoja, mm. histidiiniä, todennäköisesti enemmän rypsirehu- kuin soijaruokinnoilta. Histidiinin on todettu olevan useissa kokeissa maidontuotantoa ensimmäiseksi rajoittava aminohappo säilörehu-viljaruokinnalla (Vanhatalo ym.1999, Korhonen ym. 2002). Vaikka rypsipuristeen ja rapsirouheen välillä ei ollut yleensä merkitseviä eroja mitatuissa parametreissa, rypsipuristeella ruokittujen lehmien plasman metioniini- (20 vs. $25 \mu \mathrm{M})$ ja lysiinipitoisuudet (96 vs.114 $\mu \mathrm{M}$ ) olivat merkitsevästi pienemmät kuin rapsirouheella ruokittujen lehmien vastaavat pitoisuudet. Tämä viittaa siihen, että rypsipuristeen valmistusprosessi on saattanut alentaa näiden aminohappojen ohutsuolisulavuutta, jolloin valmistusprosessin käyttöön liittyvä odotus tuotoslisästä on jäänyt toteutumatta. Tätä oletusta tukee myös se, että laskettaessa lisävalkuaisen todellinen sulavuus Lucas'in yhtälöllä rypsipuristeen sulavuus oli selvästi pienempi (81\%) kuin rapsirouheen sulavuus (88\%). Soijarouheen lisävalkuaisen sulavuus oli $100 \%$.

Maidon valkuais- ja laktoosipitoisuuksissa ei ollut eroja, mutta maidon rasvapitoisuus pieneni rypsirehuja sisältävillä ruokinnoilla soijaruokintaan verrattuna molemmissa kokeissa. Myös maidon rasvahappokoostumuksessa ilmeni selviä eroja rypsirehu- ja soijaruokintojen välillä, ja muutokset olivat yhdenmukaisia molemmissa kokeissa. Tyydyttyneiden rasvahappojen osuus maitorasvassa pieneni ja tyydyttymättömien rasvahappojen osuus suureni rypsirehuja sisältävillä ruokinnoilla soijaruokintaan verrattuna. Rypsirehut vähensivät erityisesti palmitiinihapon $\left(\mathrm{C}_{16: 0}\right)$ osuutta ja lisäsivät steariinihapon $\left(\mathrm{C}_{18: 0}\right)$, öljyhapon $\left(\mathrm{C}_{18: 1}\right)$ ja konjugoidun linolihapon $\left(\mathrm{C}_{18: 2 \text {, konj.; }} \mathrm{CLA}\right)$ osuuksia maitorasvassa. Mainitut muutokset olivat yleensä huomattavampia rypsipuristeella kuin rapsirouheella. Rypsirehuja sisältävät dieetit lisäsivät maidon CLA-pitoisuutta keskimäärin 40 \% molemmissa kokeissa. Suurin todettu maidon CLA-pitoisuus saavutettiin kuitenkin ensimmäisessä kokeessa jo rypsipuristeen toiseksi suurimmalla annostustasolla ja jälkimmäisessä kokeessa rapsirouheannoksella.

Todetut erot maidon rasvahappokoostumuksessa liittyvät vertailtavina olevien väkirehujen erilaiseen rasvapitoisuuteen. Molemmissa kokeissa rypsipuristetta ja rapsirouhetta sisältävät väkirehut sisälsivät enemmän raakarasvaa kuin soijarouhetta sisältävä väkirehu. Soijaa sisältäneisiin ruokintoihin verrattuna lehmät saivat ensimmäisessä kokeessa lisärasvaa rypsipuristeruokinnoilla 88-238 g/d. Vastaavasti jälkimmäisessä kokeessa lehmät saivat lisärasvaa rypsipuristeesta $177 \mathrm{~g} / \mathrm{d}$ ja rapsirouheesta 71 g/d. Rypsirehut sisältävät runsaasti öljyhappoa, joka hydrogenoituu pötsissä steariinihapoksi lisäten näin steariinihapon saantia. Steariinihappo ja biohydrogenaation välituotteet kuten vakseenihappo voivat myös desaturoitua maitorauhasessa öljyhapoksi ja CLA:ksi (Griinari ym. 2000). Steariinihapon, öljyhapon cis ja trans isomeerien ja CLA:n pitoisuuksien lisääntyminen maidossa rypsirehuja sisältävillä ruokinnoilla viittaavat juuri näiden mekanismien toteutumiseen rypsirehuihin sisältyvän rasvan metaboloituessa pötsissä ja maitorauhasessa. Tulokset osoittavat, että maidon rasvahappokoostumusta on mahdollista muuttaa ravitsemuksellisesti suotuisaan suuntaan jo suhteellisen pienellä dieetin rasvapitoisuuden muutoksella. Rasvalisän käyttöön yleensä liittyviä haitallisia vaikutuksia kuten maidon valkuaispitoisuuden pienenemistä ja kuidun sulavuuden heikkenemistä, ei tapahtunut kummassakaan kokeessa.

Valkuaislisä ruokinnassa lisäsi jonkin verran ruokinnoittain (kontrolli, soijar., rypsip., ja rapsir.) mitattua juustosaalista $(10.03,10.15,10.19$ ja $10.33 \mathrm{~kg} / 1001$ maitoa, $\mathrm{SEM}=0.064, \mathrm{P}<0.04)$ jälkimmäisessä kokeessa. Varastoinnin (6 vk) jälkeen eri ruokinnoilla tuotettujen edamjuustojen arvostelupisteissä ei ollut merkitseviä eroja, ja kaikki juustot olivat laadultaan ensiluokkaisia. Rapsirouheella tuotetun juuston kypsyysindeksi oli muita pienempi osoittaen sen kypsyneen muita juustoja hitaammin.

Maitorasvan laatua ja maitorasvan stabiilisuutta tarkasteltiin rasvahappokoostumuksen lisäksi maidon antioksidanttipitoisuuksien ja muiden hapettumisalttiutta kuvaavien parametrien avulla. 
Aikaisemmissa kotimaisissa tutkimuksissa (Shingfield ym. 1999) on todettu, että esim. säilörehun valmistustapa vaikuttaa selvästi maidon vitamiinipitoisuuksiin. Nyt tehdyissä kokeissa maidon vitamiinipitoisuudet olivat samaa tasoa kuin mainitussa kotimaisessa kokeessa ruokinnan pohjautuessa muurahaishapolla säilöttyyn nurmirehuun. Valkuaislisä ruokinnassa ei juuri vaikuttanut maidon retinolin, $\beta$-karoteenin, $\alpha$-tokoferolin tai $\mathrm{C}$-vitamiinin pitoisuuksiin. Ainoastaan maidon $\beta$-karoteenipitoisuus oli soijarouhetta saaneilla lehmillä suurempi kuin rypsirehuja saaneilla lehmillä, ja maidon retinolipitoisuus suurempi rypsipuriste- kuin rapsirouheruokinnalla. Maitorasvan peroksidiluvuissa tai fysikaalisesti erotetun maitorasvan haihtuvissa hapettumistuotteissa $0,2,4$ ja 6 viikon säilytyksen (lämpötila $60^{\circ} \mathrm{C}$ ) jälkeen ei ollut suuria ruokintojen välisiä eroja. Hapettuminen lähti selkeästi käyntiin vasta 4 viikon hapettamisen jälkeen, jolloin maitorasvan haihtuvat hapettumistuotteet samoin kuin peroksidiluvut kasvoivat voimakkaimmin rypsipuristeella ruokittujen lehmien maidossa.

\section{Johtopäätökset}

Soijaa on yleisesti pidetty parempana lypsylehmien valkuaisrehuna kuin rypsiä. Tässä tutkimuksessa rypsiä ja soijaa verrattiin usealla annostustasolla ja osoitettiin, että rypsi on soijaa parempi valkuaisen lähde lypsylehmille nurmisäilörehuun perustuvassa ruokinnassa. Plasman aminohappoprofiilien perusteella on ilmeistä, että lypsylehmät saavat aminohappoja sekä laadullisesti että määrällisesti enemmän rypsirehuista kuin soijarouheesta. Soijan ja rypsin tuotosvasteista saadut tulokset yhdessä kirjallisuustarkastelun kanssa johtivat soijarouheen valkuaisarvon uudelleen arviointiin, minkä tuloksena soijarouheen valkuaisarvoa alennettiin suhteessa rypsiin. Rypsin osalta tutkimus vahvisti aikaisempia tuloksia siitä, että puristeen ja rouheen välillä ei ole eroa valkuaistuotoksessa. Rypsipuristeella ruokittujen lehmien rapsirouheruokintaan verrattuna pienemmät plasman metioniini- ja lysiinipitoisuudet sekä lisävalkuaisen huonompi todellinen sulavuus viittaavat kuitenkin siihen, että rypsipuristeen valmistusprosessi on saattanut vaikuttaa haitallisesti aminohappojen ohutsuolisulavuuteen. Mahdollisesti tästä johtuen valmistusprosessin käyttöön liittyvä odotus tuotoslisästä on jäänyt toteutumatta.

Tulokset osoittavat myös, että maidon rasvahappokoostumusta on mahdollista muuttaa ravitsemuksellisesti suotuisaan suuntaan jo suhteellisen pienellä dieetin rasvapitoisuuden muutoksella ilman rasvalisän käyttöön yleensä liittyviä haitallisia vaikutuksia. Valkuaislisällä ruokinnassa pystyttiin jonkin verran parantamaan maidon juustoutumisominaisuuksia ja juustosaaliista. Toisaalta suurillakaan valkuaisrehun annostustasoilla ei ollut negatiivista vaikutusta maidon juustoutumisominaisuuksiin. Maitorasvan kemialliset tutkimukset osoittivat, että ruokinnassa voidaan käyttää suuriakin valkuaisrehun annostustasoja ilman haitallisia vaikutuksia maidon antioksidanttipitoisuuksiin tai hapettumisalttiuteen.

\section{Kirjallisuus}

Ahvenjärvi, S, Vanhatalo, A, Huhtanen P. \& Varvikko, T. 1999. Effects of supplementation of a grass silage and barley diet with urea, rapeseed meal and heat-moisture treated rapeseed cake on milk production and omasal digesta flow in lactating dairy cows. Acta Agriculturae Scandinavica, Section A Animal Science 49: 179-189.

Griinari, J.M., Corl, B.A., Lacy, S.H., Chouinard, P.Y., Nurmela, K.V.V. \& Bauman, D.E. 2000. Conjugated linoleic acid is synthesized endogenously in lactaing dairy cows by delta-9-desaturase. Journal of Nutrition 130:22852291.

Huhtanen, P. 1998. Supply of nutrients and productive responses in dairy cows given diets based on restrictively fermented grass silage. Agricultural and Food Science in Finland 7: 219-250.

Korhonen, M., Vanhatalo, A. \& Huhtanen, P. 2002. Effect of protein source on amino acid supply, milk production and metabolism of plasma nutrients in dairy cows fed grass silage. Journal of Dairy Science 85:33363351.

Rinne, M., Jaakkola, S., Varvikko, T. \& Huhtanen, P. 1999. Effects of the type and amount of rapeseed feed on milk production. Acta Agriculturae Scandinavica, Section A Animal Science 49: 137-148.

Shingfield, K.J., Jaakkola, S. and Huhtanen, P., Pahkala, E., Lehdonkivi, T., Korhonen, H., Salo-Väänänen, P. \& Piironen, V. 1999. Keskeisten alkutuotantotekijöiden ja prosessoinnin vaikutus maidon laatuun. Julkaisussa: Maidon uudet sovellutukset. Toim. Hannu Korhonen \& Pirjo Rantamäki. Maatalouden tutkimuskeskuksen julkaisuja. Sarja A. s. 54-66.

Vanhatalo, A, Huhtanen, P., Toivonen, V.\& Varvikko, T. 1999. Response of dairy cows fed grass silage diets to abomasal infusions of histidine alone or in combinations with methionine and lysine. Journal of Dairy Science 82: 674-2685. 
Taulukko 1. Valkuaistason vaikutus rehujen syöntiin, maitotuotokseen ja plasman parametreihin

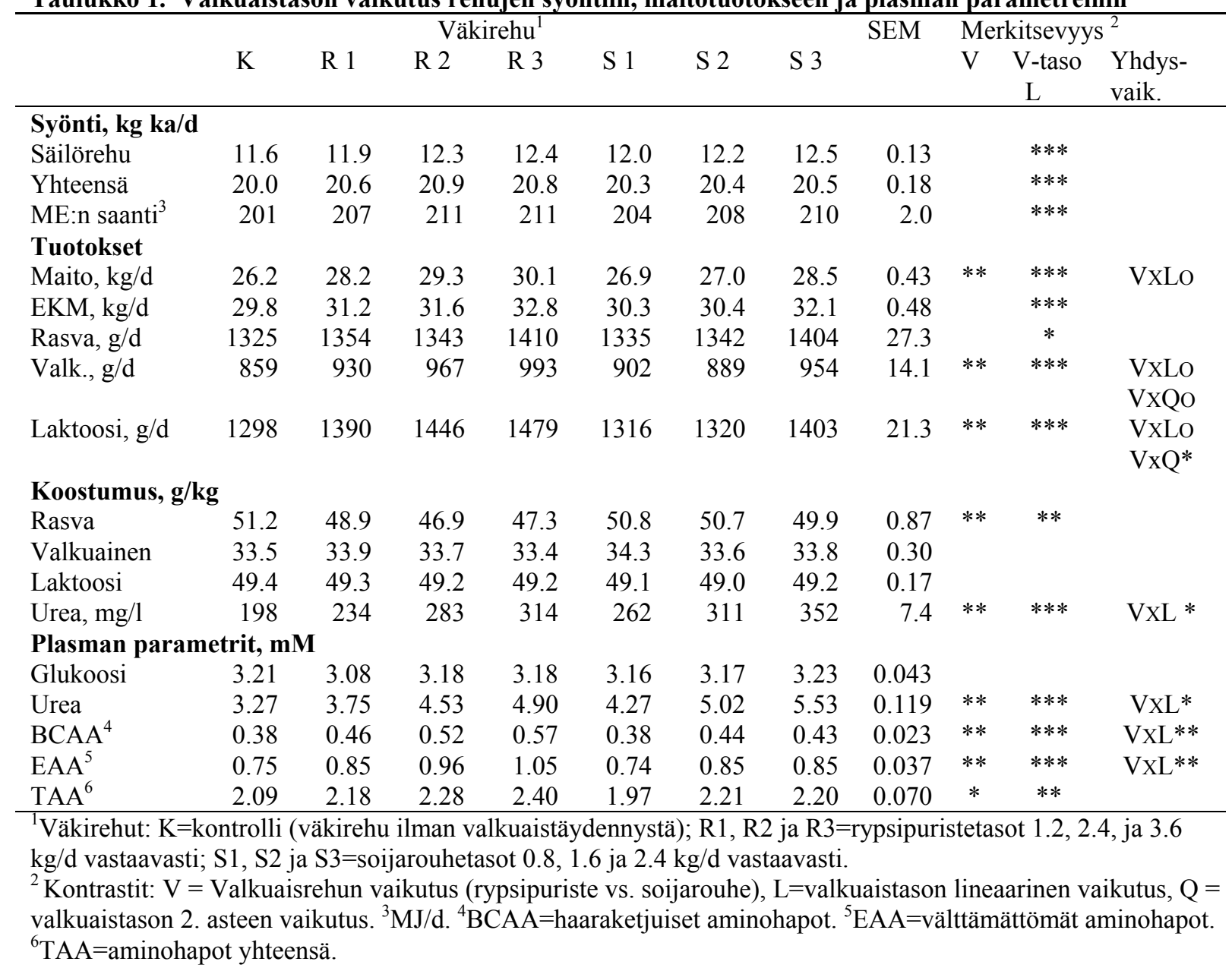

Taulukko 2. Valkuaislisän vaikutus rehujen syöntiin, maitotuotokseen ja plasman parametreihin

\begin{tabular}{|c|c|c|c|c|c|c|c|c|}
\hline & $\mathrm{K}$ & Soijar. & Rypsip. & Rapsir. & SEM & $\mathrm{C} 1$ & $\mathrm{C} 2$ & $\mathrm{C} 3$ \\
\hline \multicolumn{9}{|l|}{ Syönti, kg ka/d } \\
\hline Säilörehu & 10.7 & 11.1 & 11.3 & 11.5 & 0.12 & $* * *$ & $*$ & \\
\hline Yhteensä & 19.1 & 19.6 & 19.8 & 20.0 & 0.12 & $* * *$ & $*$ & \\
\hline ME:n saanti, MJ/d & 197 & 209 & 210 & 214 & 1.4 & $* * *$ & & o \\
\hline \multicolumn{9}{|l|}{ Tuotokset, kg/d } \\
\hline Maito & 26.6 & 28.4 & 29.8 & 29.3 & 0.23 & $* * *$ & $* * *$ & \\
\hline EKM & 29.0 & 31.2 & 31.7 & 31.3 & 0.21 & $* * *$ & & \\
\hline Valkuainen, g/d & 889 & 950 & 996 & 991 & 7.2 & $* * *$ & $* * *$ & \\
\hline Laktoosi, g/d & 1314 & 1399 & 1468 & 1439 & 11.7 & $* * *$ & $* * *$ & $\mathrm{o}$ \\
\hline Rasva, g/d & 1232 & 1335 & 1316 & 1305 & 13.4 & $* * *$ & & \\
\hline \multicolumn{9}{|l|}{ Koostumus, g/kg } \\
\hline Valkuainen & 33.6 & 33.8 & 33.7 & 34.1 & 0.20 & & & \\
\hline Laktoosi & 49.4 & 49.4 & 49.3 & 49.2 & 0.09 & & & \\
\hline Rasva & 46.2 & 47.0 & 44.2 & 44.5 & 0.47 & o & $* * *$ & \\
\hline Urea, mg/l & 166 & 309 & 277 & 287 & 6.2 & $* * *$ & $* * *$ & \\
\hline \multicolumn{9}{|c|}{ Plasman parametrit, $\mathbf{m M}$} \\
\hline Glukoosi & 3.36 & 3.46 & 3.35 & 3.33 & 0.034 & & $* *$ & \\
\hline Urea & 2.93 & 5.60 & 4.90 & 4.90 & 0.104 & $* * *$ & $* * *$ & \\
\hline BCAA & 0.46 & 0.52 & 0.58 & 0.59 & 0.015 & $* * *$ & $* * *$ & \\
\hline EAA & 0.84 & 0.95 & 1.04 & 1.10 & 0.027 & $* * *$ & $* * *$ & \\
\hline TAA & 2.08 & 2.16 & 2.24 & 2.24 & 0.054 & $* *$ & $*$ & \\
\hline
\end{tabular}

$\mathrm{K}=$ kontrolli (väkirehu ilman valkuaistäydennystä); Soijar.= väkirehu sis. soijarouhetta; Rypsip.=väkirehu sis. rypsipuristetta; Rapsir.=väkirehu sis. rapsirouhetta. www.agronet.fi/maataloustieteellinenseura 